PREPARED IN COOPERATION WITH

THE PENNSYLVANIA DEPARTMENT OF ENVIRONMENTAL RESOURCES BUREAU OF TOPOGRAPHIC AND GEOLOGIC SURVEYS

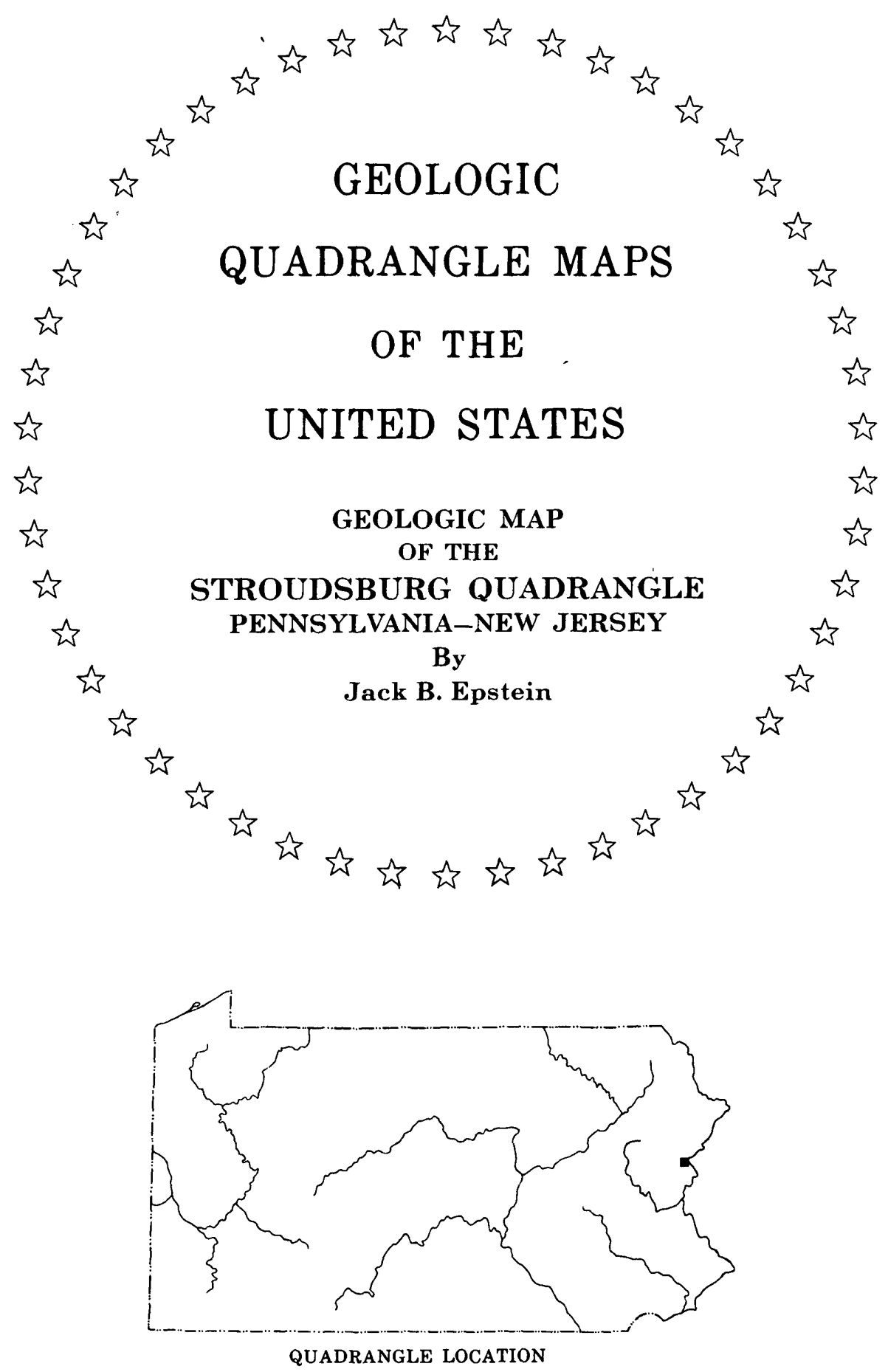

PUBLISHED BY THE U.S. GEOLOGICAL SURVEY 


\title{
GEOLOGIC MAP OF THE STROUDSBURG QUADRANGLE, PENNSYLVANIA-NEW JERSEY
}

\section{By}

\author{
Jack B. Epstein
}

\section{INTRODUCTION}

The Stroudsburg quadrangle is in the Valley and Ridge and Great Valley physiographic provinces. The locations of wind and water gaps in the ridges are structurally controlled, rather than controlled by regional superposition as commonly thought (Epstein, 1966). Pre-existing topography strongly influenced the direction of travel of the Wisconsin glacier, the manner of its retreat, and the deposits that were formed (Epstein, 1969). Bedrock consists of many complexly folded heterogeneous stratigraphic units. Because of lithologic dissimilarities, certain major stratigraphic sequences-lithotectonic units-were deformed semi-independently of rocks above and below them during the Appalachian orogeny. Structural features produced by the Taconic orogeny are less obvious in the quadrangle but probably include gentle folds and large thrust faults. This orogeny produced a thick synorogenic flysch sequence (Martinsburg Formation) followed by a thick molasse sequence (predominantly continental clastic wedge). These are overlain by shallowmarine sediments. The geologic relations of the Stroudsburg quadrangle to surrounding areas have been discussed by Epstein and Epstein $(1967,1969)$. The geology of the quadrangle is summarized below; a more detailed report and alternate interpretations have been given by Epstein.(1971).

\section{ENVIRONMENTS OF DEPOSITION}

The sequence of rocks from the Middle Ordovician through part of the Middle Devonian composes a flysch-molasse-carbonate-orthoquartzite shelf succession. The rhythmically graded sequences of graywacke turbidites and slate of the Martinsburg Formation indicate basin deepening during the early part of the Taconic orogeny. Details of Martinsburg sedimentation have been given by McBride (1962): In Late Ordovician time the orogeny reached its peak, and the area was uplifted above sea level. This resulted in the deposition of a thick, predominantly continental, clastic wedge during the Silurian (Shawangunk-Bloomsburg interval) derived from sourcelands to the southeast.

Initially, uplift was rapid, as evidenced by the coarse-textured basal Shawangunk (Minsi Member) rocks. These rocks are characterized by rapidly alternating planar-bedded to crossbedded partly conglomeratic sandstones indicative of relatively rapid flow (upper lower to upper flow regime) and are probably stream-channel and bar deposits. Grain size is variable, ranging from medium to very coarse grained, and pebbles are well rounded to subangular. The sandstones are generally immature with a muscovite-chlorite-rich matrix. Paleocurrent trends are unidirectional to the northwest: Bed forms and sedimentary structures indicate deposition by streams with high competency, steep gradients, and low sinuosity (braided). The lack of channel-fill deposits with relief greater than 5 feet also indicates that the streams flowed in shifting anastomosing channels. The small amount of shale and siltstone, probably representing overbank or backwater deposits, is characteristic of a braided pattern with efficient removal of these fine materials by the shifting channels. Some mud was incorporated in the coarser sediments as flattened balls. Mudcracked siltstone in Delaware Water Gap in the adjoining Portland quadrangle shows that these deposits were subject to subaerial exposure.

The maturity of the pebbles (quartz, chert, and quartzite) and heavy minerals (predominantly zircon and tourmaline with minor rutile), as well as the low feldspar content, suggest a predominantly sedimentary source.
The succeeding Lizard Creek Member accumulated in a complex transitional (continental-marine) transgressive environment and contains tidal-flat, tidal-channel and gully, and shallow subtidal-estuary, fluviatile, lagoon, and barrier-bar of beach deposits. The tidal-flat deposits consist of irregularly interlaminated to interbedded burrowed shale, siltstone, and rippletopped sandstone. Ripple lensing is common and is analogous to features in modern sediments reworked by tidal currents or carried out to deeper subtidal areas during storms. Crossbedded sandstones that contain mud clasts may be tidal-channel or tidalgully deposits. Thicker crossbedded sandstones; similar to those in members above and below, are fluviatile deposits that prograded out onto flats or are possibly estuarine deposits. Evenbedded to planar-laminated mature sandstones with primary current lineation are believed to be beach or barrier-bar deposits. Some finely laminated silt and fine sand probably were laid down in lagoons behind the bars.

The Lizard Creek Member is succeeded by a regressive sandstone-conglomerate unit (Tammany Member), which was deposited under fluviatile conditions similar to those of the Minsi Member. A more detailed description of Shawangunk rocks is given by Epstein and Epstein (1972).

Fluviatile conditions persisted into Bloomsburg time, but the fining-upward cycles and greater percentage of finer siltstone and shale in the Bloomsburg indicate that the braided patterns characteristic of the Tammany Member gave way to meandering streams as the southeastern source area was progressively lowered by erosion. The coarser basal sands of a typical Bloomsburg cycle were deposited in stream channels or point bars. Incorporated mud clasts were derived from bank caving. The overlying planar-laminated and cross-laminated sandstone and siltstonein acycleindicate decreasing flow regime and are interpreted to be levee and crevasse-splay deposits. Commonly these are succeeded by burrow-mottled to laminated, mudcracked silty shale and siltstone with calcareous dolomite concretions, indicative of low-energy fine overbank of flood-plain accumulations.

The sediments deposited after the end of molasse sedimentation in Bloomsburg time, up to and including those of the Oriskany Group, are a marine shelf carbonate-orthoquartzite facies. During Poxono Island to Coeymans time the rates of sedimentation and basin sinking were about equal, so that the area was maintained near sea level, and an alternating complex of tidal flats (supratidal and intertidal) and barrier bars or biostromal banks (intertidal and shallow subtidal) was maintained.

Supratidal deposits in the Poxono Island Formation, Bossardville Limestone, and Rondout Formation are characterized by (1) laminations of organo-(algal) sedimentary origin; (2) slightly quartzose, dominantly very fine to fine-grained laminated and very thin bedded to massive dolomite, limestone, and interlaminated dolomite and limestone; (3) very restricted fauna (mainly leperditiid ostracodes); and (4) mudcracks.

Intertidal flat sediments in the Poxono Island Formation, Bossardville Limestone, Rondout Formation, and Depue Limestone Member of the Coeymans Formation, are characterized by (1) generally graded and rippled laminae to thin beds of slightly quartzose very fine to medium-grained limestone; (2) cut-andfill structure, small-scale crossbedding, and intraclasts; (3) abundant ostracodes (mainly leperditiids); (4) scattered beds containing a diverse marine fauna believed to be storm-tossed skeletal debris on a tidal flat behind a barrier bar; and (5) rare mudcracks. 
Barrier-bar deposits in the Decker Formation, Peters Valley and Stormville Members of the Coeymans Formation; and Oriskany Group are characterized by (1) quartzose fine- to coarse-grained limestone and calcareous sandstone and conglomerate containing foreshore laminations and large-scale crossbedding; (2) cut-and-fill structure and intraclasts; (3) abundant skeletal debris of a variety of marine organisms; and (4) scattered burrows.

During Coeymans through most of Port Ewen time, a major marine transgression took place, followed by a late Port EwenOriskany regression. The Shawnee Island Member of the Coeymans Formation accumulated in a subtidal biostromal-bank zone not far from shore and sources of clastic (quartz) sediment influx. At the same time, reefs flourished in adjacent quadrangles (Epstein and others, 1967). The reefs and banks were buried by barrier bars during Stormville time. Deeper neritic sediments, characterized by cherty burrowed calcilutite and calcisiltite and very fossiliferous limestone beds and lenses with abundant benthonic fauna and less fossiliferous laminated calcisiltite subsequently were deposited during New Scotland, Minisink, and Port Ewen time. Basin shallowing began in late Port Ewen time and culminated in the coarse clastic beach deposits of the Ridgely Sandstone of the Oriskany Group which contains thickshelled wave-resistant Spirifer arenosus.

Deep neritic conditions were reestablished in Esopus-early Schoharie time, and widespread siltstones with lateral burrows (Taonurus) and rare skeletal debris were deposited. Basin shallowing continued and produced depths within the photic zone that contained warm, well-oxygenated, and gently circulating water. These conditions are indicated by the upward increase in diverse marine faunas, vertical burrows, and amount of limestone in the upper Schoharie Formatiom and Buttermilk Falls Limestone.

The carbonaceous, pyritic, sparsely fossiliferous, laminated shales of the Marcellus were probably deposited below wave base in a reducing environment and indicate basin deepening. More rapid and intermittent sedimentation occured during shallowing in Mahantango time. These conditions are reflected by abundant fossils, coquinite lenses, and the Centerfield biostrome that contains abundant corals.

\section{STRUCTURAL GEOLOGY}

Four rock sequences of differing lithology and competencylithotectonic units-have different styles of deformation in the Stroudsburg quadrangle (table 1). Each lithotectonic unit has been deformed semi-independently of rocks above and below and is interpreted to be set off from the other units by décollements (detachments along a basal shearing plane or zone). Type and amplitude of folds are controlled by lithic variations within each lithotectonic unit, and as a result folding is disharmonic (see cross sections).

The Martinsburg-Shawangunk contact (Blue Mountain décollement) is a detachment between lithotectonic units 1 and 2. The contact is not exposed in the quadrangle, but elsewhere in easternmost Pennsylvania it is marked by thin fault gouge and breccia and by bedding-plane slickensides with microscarps or steps, as well as drag folds, indicating northwest movement of the overlying Shaw angunk Formation.

A thick detachment zone, the Godfrey Ridge décollement, is inferred to separate lithotectonic units 2 and 3 . The change in style of deformation between the two units takes place in the Poxono Island Formation, but considerable northwest movement is indicated by wedging and bedding slip in the Bloomsburg Red Beds of lithotectonic unit 2 and is well shown in outcrops in Delaware Water Gap in the northeast corner of the quadrangle. The net telescoping in the Bloomsburg may amount to thousands of feet or miles. Rocks in lithotectonic unit 3 were shortened 15 percent more than rocks in lithotectonic unit 2 , as shown in the cross sections, that is, if all the complex folding is considered to be flexural slip. However, some of the folding was by passive slip, so the net shortening is somewhat less than 15 percent.
On the basis of the difference in fold geometry between lithotectonic units 3 and 4 , differential movement appears to have occurred within the Marcellus Shale, but outcrops that would provide evidence of the Weir Mountain décollement are lacking. In addition to this northwest-dipping décollement, a southeastdipping thrust fault, known in this interval of rock about 20 miles to the southwest (the Sweet Arrow fault of Wood and Kehn, 1961), may separate rocks of lithotectonic units 3 and 4 in the Stroudsburg quadrangle. Proof of the fault's existence must await completion of mapping immediately to the southwest; data in the Stroudsburg quadrangle are insufficient to indicate its presence.

The detachment zones are folded but generally dip to the northwest. No obvious root zone is known. Therefore, northwest movement into the Appalachian basin may have been primarily by gravitational sliding from uplifted areas to the southeast. If the bedding slippage in the Bloomsburg Red Beds is part of the overall movement in the décollement zone, folding and the formation of axial-plane cleavage was already underway during the final phases of sliding because the cleavage is deformed at slippage planes and it appears to fan the major folds. Sliding probably began soon after initial uplift, however, and sliding, folding, and cleavage development were probably overlapping events during continuous deformation. Upward shearing of these décollements, as described by Gwinn (1964) in central Pennsylvania, has not been observed in the quadrangle. Possibly these décollements are similar to or continuous with those described to the south west by Gwinn.

Examples of small-scale internal disharmonic folding are numerous in all lithotectonic units in the quadrangle and surrounding areas. In Delaware Water Gap, for example, small undulations are superimposed on the larger Dunnfield Creek syncline. There, several bedding-plane faults locally shear off the tops of anticlines. The universal southeast dip of cleavage in all parts of the folds and external rotation of cleavage by the small-scale folding indicate that both the cleavage and the folds developed during one period of continued deformation. However, the relative ages of the structures (overlapping to some extent) seen in the Bloomsburg in Delaware Water Gap seem to be (1) folding of the Dunnfield Creek syncline; (2) development of the small folds in the syncline, perhaps by sliding; (3) continued development of cleavage, probably during continued folding of the Dunnfield Creek syncline; and (4) bedding-plane slip and wedging.

Chronology of deformation. - The relative effects of the Taconic and Appalachian orogenies in eastern Pennsylvania have been controversial for more than 100 years (see summary in Epstein and Epstein, 1969). On the basis of data from the Stroudsburg quadrangle and surrounding areas, it is concluded that (1) there is an angular unconformity ascribable to the Taconic orogeny between the Martinsburg and Shawangunk Formations, and the Silurian clastic wedge was the result of mountain building and erosion after the orogeny; (2) the prominent slaty cleavage in the Martinsburg and younger rocks is Appalachian in age; (3) most of the folds in the quadrangle are Appalachian in age, although, in the Martinsburg, they may be superimposed on the upper limb of a large regional nappe believed to be of Taconic age (Drake and Epstein, 1967; Drake, 1969); (4) gentle folds in the Martinsburg (seen in the cross sections directly under the Shawangunk) and the Portland fault do not appear in younger rocks, and are believed therefore to be Taconic structures.

The reasoning for these conclusions stems from work in the Delaware and Lehigh Valleys (Epstein and Epstein, 1969, p. 165-170; Epstein, 1971). Briefly, some of the germane data and conclusions in the Stroudsburg quadrangle are:

(1) The northwest-dipping cleavage in the Martinsburg within 2,000 feet of the Shawangunk contact is believed to be due to pressure-shadow fanning during post-Shawangunk deformation rather than to folding of Taconic cleavage.

(2) No fragments of Martinsburg slate have been found in basal Shawangunk beds in the quadrangle. 
(3) The trends of cleavage in the Martinsburg Formation and younger pelitic units are similar in the Stroudsburg quadrangle. Southeast and southwest of the quadrangle, Martinsburg cleavage is folded and a second (slip) cleavage is developed, indicating that deformation increases in those directions. Slip cleavage is also found locally in rocks younger than the Martinsburg.

(4) The cleavage in the Martinsburg has not been rotated to conform to folds in overlying rocks. Rather, the cleavage appears to be nearly parallel to the axial planes of those folds.

Many recent workers have suggested that slate is of nonmetamorphic (diagenetic) origin and was formed by slight rapidly applied tectonic pressure that approached lithostatic pressure causing fluid expulsion and consequent mineral alinement in water-bearing muds. This concept of tectonic dewatering was first suggested by Maxwell (1962) for cleavage in the Martinsburg in the Delaware Water Gap area. I conclude, however, that the slate in the Martinsburg is a metamorphic rock (lower greenschist facies). The pertinent data that follow do not preclude initiation of development of cleavage as described by Maxwell His dewatering mechanism could have been effective under conditions of low-grade metamorphism, or, more likely, it may have begun early during continuous deformation that ultimately produced a metamorphic rock.
(1) Mineral alinement parallel to walls of some dikes of pelite in sandstone shows that soft-rock reorientation did occur. In thin section, however, the prominent regional slaty cleavage cuts this earlier mineral alinement.

(2) Bedding-plane slickensides are deformed by slaty cleavage, indicating that the Martinsburg was competent enough to deform by flexural slip prior to development of the cleavage. This does not support the hypothesis that the cleavage was imposed on the soft water-bearing muds.

(3) Thin-section examination shows that chlorite and muscovite porphyroblasts have grown in the cleavage. X-ray analyses show that albite is present in Martinsburg slates except where slaty cleavage in the Martinsburg is indistinct or absent, as in pressure-shadow areas near the Shawangunk Formation.

(4) The mica in the slate is not diagenetic "illite," or $1 \mathrm{M}$ muscovite, but rather the $2 \mathrm{M}$ polymorph of muscovite.

These data indicate that the slate in the Martinsburg developed in the quartz-muscovite-albite-chlorite subfacies of the greenschist facies. In addition, study of all rocks in the quadrangle suggests that the regional cleavage is due to laminar flow of pelitic material along cleavage folia accompanied by mechanical reorientation of platy and elongate minerals and neocrystallization of mica, quartz, chlorite, and probably albite.

\section{REFERENCES CITED}

Alvord, D.C., and Drake, A. A., Jr., 1971, Geologic map of the Bushkill quadrangle, Pennsylvania-New Jersey: U.S. Geol. Survey Geol. Quad. Map GQ-908.

Davis, R. E., Drake, A. A., Jr., and Epstein, J. B., 1967, Geologic map of the Bangor quadrangle, Pennsylvania-New Jersey: U.S. Geol. Survey Geol. Quad. Map GQ-665.

Drake, A. A., Jr., 1969, Precambrian and lower Paleozoic geology of the Delaware Valley, New Jersey-Pennsylvania, in Subitzky, Seymour, ed., Geology of selected areas in New Jersey and Pennsylvania and guidebook of excursions: New Brunswick, N. J., Rutgers Univ. Press, p. 51-131.

Drake, A. A., Jr., and Epstein, J. B., 1967, The Martinsburg Formation (Middle and Upper Ordovician) in the Delaware Valley., Pennsylvania-New Jersey: U.S. Geol. Survey Bull. 1244-H, p. H1-H16

Drake, A. A., Jr., Epstein, J. B., and Aaron, J. M., 1969, Geologic map and sections of parts of the Portland and Belvidere quadrangles, New Jersey-Pennsylvania: U.S. Geol. Survey Misc. Geol. Inv. Map I-552

Epstein, A. G., Epstein, J. B., Spink, W. J., and Jennings, D. S., 1967, Upper Silurian and Lower Devonian stratigraphy of northeastern Pennsylvania, New Jersey, and southeasternmost New York: U.S. Geol. Survey Bull. 1243, 74 p.

Epstein, J. B., 1966, Structural control of wind gaps and water gaps and of stream capture in the Stroudsburg area, Pennsylvania and New Jersey: U.S. Geol. Survey Prof. Paper 550-B, p. B80-B86.

1969, Surficial geology of the Stroudsburg quadrangle, Pennsylvania-New Jersey: Pennsylvania Geol. Survey, 4th ser., Bull. G57,67 p.
1971, Geology of the Stroudsburg quadrangle and adjacent areas, Pennsylvania-New Jersey: U.S. Geol. Survey open-file report, $339 \mathrm{p}$.

Epstein, J. B., and Epstein, A. G., 1967, Geology in the region of the Delaware to Lehigh Water Gaps: Field Conference of Pennsylvania Geologists, 32nd, East Stroudsburg, Sept. 1967, Guidebook, 89 p. (Harrisburg, Pa., Pennsylvania Geol. Survey).

1969, Geology of the Valley and. Ridge province between Delaware Water Gap and Lehigh Gap, Pennsylvania, in Subitzky, Seymour, ed., Geology of selected areas in New Jersey and Pennsylvania and guidebook of excursions: New Brunswick, N. J., Rutgers Univ. Press, p. 132-205.

1972, The Shawangunk Formation (Upper Ordovician(?) to Middle Silurian) in eastern Pennsylvania: U.S. Geol. Survey Prof. Paper 744.

Gwinn, V. E., 1964, Thin-skinned tectonics in the Plateau and northwestern Valley and Ridge provinces of the central Appalachians: Geol. Soc. America Bull., v. 75, no. 9, p. 863900.

Maxwell, J. C., 1962, Origin of slaty and fracture cleavage in the Delaware Water Gap area, New Jersey and Pennsylvania, in Geol. Soc. America, Petrologic studies: a volume in honor of A. F. Buddington: New York, Geol. Soc. America, p. 281311.

McBride, E. F., 1962, Flysch and associated beds of the Martinsburg Formation (Ordovician), central Appalachians: Jour. Sed. Petrology, v. 32, no. 1, p. 39-91.

Wood, G. H., Jr., and Kehn, T. M., 1961, Sweet Arrow fault, east-central Pennsylvania: Am. Assoc. Petroleum Geologists Bull., v. 45, no. 2, p. 256-263. 